\title{
Trophic cascades mediated by copepods, not nutrient supply rate, determine the development of picocyanobacteria
}

\author{
Line E. Sundt-Hansen ${ }^{1,5}$, Yngvar Olsen ${ }^{1}$, Herwig Stibor ${ }^{2}$, Mikal Heldal ${ }^{3}$, \\ Olav Vadstein ${ }^{4, *}$ \\ ${ }^{1}$ Norwegian University of Science and Technology, Department of Biology, Trondhjem Biological Station, \\ 7491 Trondheim, Norway \\ ${ }^{2}$ Department of Biology II, Aquatic Ecology Group, Ludwig-Maximilians-Universität München, Karlstrasse 23-25, \\ Grosshaderner Strasse 2, 82152 Planegg, Germany \\ ${ }^{3}$ University of Bergen, Department of Biology, Jahnebakken 5, 5020 Bergen, Norway \\ ${ }^{4}$ Norwegian University of Science and Technology, Department of Biotechnology, 7491 Trondheim, Norway \\ ${ }^{5}$ Present address: Norwegian Institute for Nature Research, Unit of Fish Ecology, Tungasletta 2, 7485 Trondheim, Norway
}

\begin{abstract}
We studied the effect of nutrient supply rate (resources) and concentrations of copepods (top predator) on picocyanbacteria (PCY) in experimental ecosystems (mesocosms) using gradients of both nutrients and predators. The biomass and production of PCY, and the biomass and predation rates of their predators were determined by epifluorescence microscopy, X-ray microanalysis (XRMA), the ${ }^{14} \mathrm{C}$ method, and cell counting by microscopy. PCY biomass did not change significantly with increased supply of nutrients, but it was positively correlated with copepod biomass. A lack of variation in PCY growth rates, and nutrient saturation of cells as suggested by nutrient analysis and XRMA measurements, indicate that PCY grew close to their maximum growth rate during the experiment. Appendicularia and ciliates were the main predators on PCY when copepod biomass was normal or low, whereas heterotrophic nanoflagellates were significant predators on PCY when copepod biomass was high. Based on a negative effect of copepod biomass on the biomass of PCY predators, we conclude that predation had a stronger effect on the development of PCY than did nutrient supply rate. The only effect of nutrient supply was negative and indirect, implemented through stimulation of predatory ciliates. Copepods had a profound effect by structuring the food web, and thus directly and indirectly regulating the abundances of predators of PCY (top-down control). Therefore, copepods indirectly controlled the abundance of PCY through trophic cascades.
\end{abstract}

KEY WORDS: Trophic cascade - Resource limitation · Nutrients - Ciliates · Appendicularia · Top-down $\cdot$ Bottom-up

\section{INTRODUCTION}

Picocyanobacteria (PCY) are ubiquitous prokaryotic autotrophic organisms that often represent a major fraction of the phytoplankton biomass (Johnson \& Sieburth 1979, Waterbury et al. 1979) and are major contributors to primary production in both marine and freshwater communities (Stockner 1988, Olsen et al. 2006). Extensive research efforts have been made to study PCY biomass and their seasonal variations in marine and freshwater systems. However, few studies report the production and fate of PCY in their natural environments, including their role in the microbial loop and the food web in general. Because of their high surface-to-volume ratio, PCY are assumed to be efficient in nutrient uptake at low nutrient concentrations. It has been suggested that nutrient concentrations in natural waters are in excess of what is required by PCY 
to maintain maximum growth rates (Raven 1986, Moutin et al. 2002).

Fig. 1 illustrates factors believed to regulate the specific growth $(\mu)$ and mortality rates $(m)$ of PCY. The specific changes in a PCY population can be described by:

$$
\frac{\mathrm{d} N}{\mathrm{~d} t} \frac{1}{N}=r=\mu-m
$$

where $\frac{\mathrm{d} N}{\mathrm{~d} t}$ is the change in biomass $(N)$ over time $(t)$, and $r$ is the specific net rate of change (all rates in $\mathrm{d}^{-1}$ ). Based on current knowledge, the overall mortality rate $(m)$ of PCY can be split into 3 components: predation $(P)$, viral lysis $(V)$ and sedimentation $(S)$. The main predators on PCY in marine systems are assumed to be heterotrophic nanoflagellates $(\mathrm{HNF})\left(P_{\mathrm{H}}\right)$, ciliates $\left(P_{\mathrm{C}}\right)$, and appendicularia $\left(P_{\mathrm{A}}\right)$.

HNF have generally been assumed to be the major consumers of autotrophic picoplankton (Weisse 1993), and studies have demonstrated that PCY, in addition to heterotrophic bacteria, make up the majority of the diet of HNF (Dolan \& Šimek 1999). Studies from both freshwater and marine environments suggest that

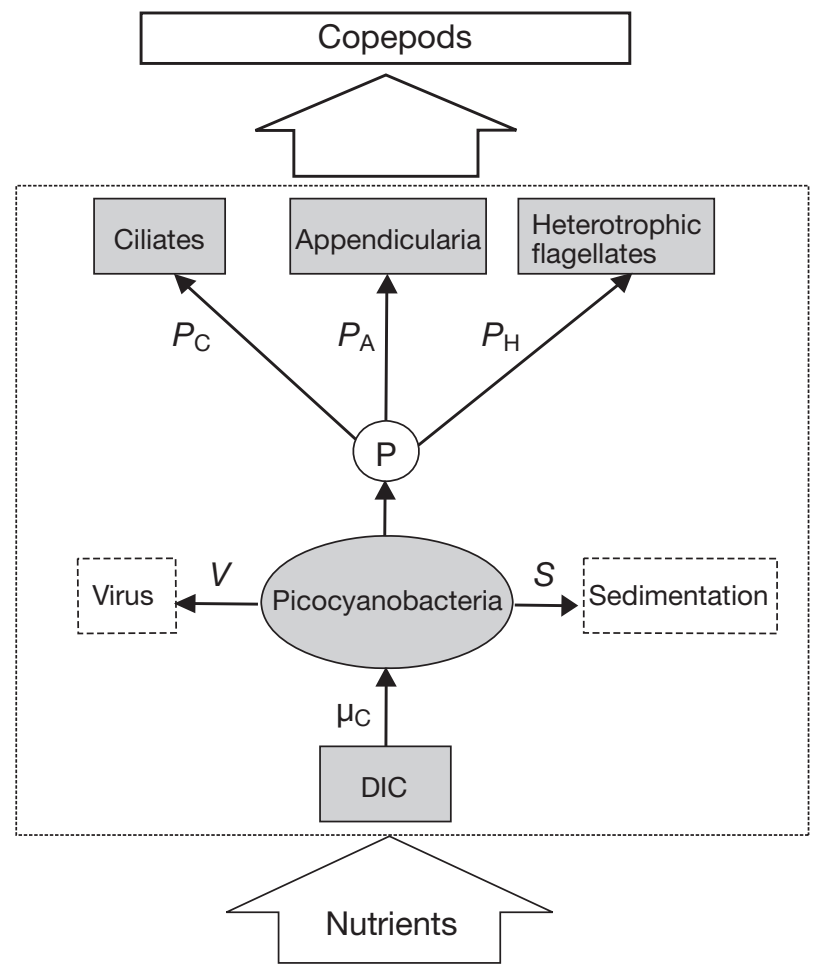

Fig. 1. Food web structure with main focus on carbon sources and sinks of picocyanobacteria (PCY) biomass. Dashed lines enclose factors that have not been studied. $\mu_{\mathrm{c}}$ : specific growth rate of PCY; $V=$ mortality due to viral infection; $S=$ mortality due to sedimentation; $P_{\mathrm{X}}=$ mortality due to predation by ciliates (C), appendicularia (A) and heterotrophic nanoflagellates $(\mathrm{H})$ small ciliates are also important predators of PCY (Šimek et al. 1996, Christaki et al. 1999). A compilation carried out by Hansen et al. (1994) showed that the optimum size ratio (based on equivalent spherical diameter, ESD) between ciliates and their prey was 8:1, and with $50 \%$ efficiencies at ratios of $6: 1$ and 13:1. PCY are typically $1 \mu \mathrm{m}$ in size; therefore, only smaller ciliates fit this optimal predator-prey size ratio. Also, appendicularia have been shown to feed on heterotrophic bacteria and PCY (Nakamura et al. 1997), despite the fact that appendicularia are several orders of magnitude larger in size. The food-concentrating filter of appendicularia is capable of retaining both pico- and nanoplankton (Flood 1978). Sedimentation rates $(S)$ of single cells of PCY can be assumed to be negligible $(S \approx 0)$ because the cells are so small (Weisse 1993). However, picoplankton can associate on organic aggregates and sink below the euphotic zone (Waite et al. 2000). Studies have suggested that viral infection may be an important factor of the mortality of PCY (Ortmann et al. 2002). Recent studies suggested that lytic viral infections removed approximately $27 \%$ of the production of heterotrophic bacteria in seawater, but as little as $1 \%$ of PCY production (Ortmann et al. 2002). Lu et al. (2001) estimated $m$ in the range of 5 to $14 \%$ as a result of viral infection of Synechococcus spp.

The main goal of this study was to examine how the structure and function of a planktonic food web were affected by variable nutrient supply rates and concentrations of copepods in experimental ecosystems (Fig. 1). Previous research has shown how these 2 experimental variables determine population dynamics of the appendicularian Oikopleura dioica (Stibor et al. 2004a) and the interaction between phytoplankton and ciliates (Vadstein et al. 2004). The present study focuses on the production and fate of PCY. Nutrient addition may directly affect growth and biomass of PCY, whereas a potential effect of variable copepod concentration will be indirect through trophic cascades. We aimed to determine how these 2 factors in concert affect the limiting factors, biomass, growth and mortality of PCY. We constructed 6 mesocosms that included 2 levels of nutrient addition and 3 levels of copepod concentration, and ran the experiment for $10 \mathrm{~d}$.

\section{MATERIALS AND METHODS}

Experimental design and general characteristics. Details of mesocosm operation and nutrient addition regime were presented by Vadstein et al. (2004). The mesocosm experiment consisted of 6 bags, with nutrient supply rate $(\mathrm{N}, \mathrm{P}, \mathrm{Si})$ as one experimental factor and copepod biomass as the other. The experiment 
was carried out in Hopavågen, Norway $\left(63^{\circ} 36^{\prime} \mathrm{N}\right.$, $9^{\circ} 33^{\prime} \mathrm{E}$ ) in mesocosms of ca. $4 \mathrm{~m}^{3}$. Copepods were maintained at 3 concentration levels: low (removal of copepods), ambient (in situ concentration), and enhanced (addition of copepods). To each copepod concentration, 2 different nutrient addition regimes were applied: normal (0.5 mg $\left.\mathrm{P} \mathrm{m}^{-3} \mathrm{~d}^{-1}\right)$ and high $(2.5 \mathrm{mg} \mathrm{P}$ $\mathrm{m}^{-3} \mathrm{~d}^{-1}$ ). The normal dose was comparable to the natural nutrient input rate (authors' unpubl. data). Inorganic nutrients were added in atomic ratios of: 16:16:1 for $\mathrm{Si}: \mathrm{N}: \mathrm{P}$, and 1:1 for nitrate and ammonia. Nutrients were added daily. The 6 mesocosms were denoted: LN (low copepod concentration, normal dose of nutrients), AN (ambient copepod concentration, normal dose of nutrients), EN (enhanced copepod concentration, normal dose of nutrients), LH (low copepod concentration, high dose of nutrients), AH (ambient copepod concentration, high dose of nutrients), and EH (enhanced copepod concentration, high dose of nutrients).

Integrated water samples from 0 to $6 \mathrm{~m}$ were collected daily at 07:00 to 08:00 h from each mesocosm using a $2 \mathrm{~m}$ long Ramberg tube sampler, and transferred to 251 low-transparency bottles that were used for sub-sampling. Samples $(100 \mathrm{ml})$ for counts of PCY and HNF were fixed with EDTA solution and glutaraldehyde (final conc. $0.45 \mathrm{mM}$ and $1 \%$, respectively), whereas samples for determination of the biomass of ciliates were fixed with acid Lugols solution ( $1 \%$ final conc.). Average temperature and salinity throughout the experiment were $12^{\circ} \mathrm{C}$ and $30 \mathrm{PSU}$, respectively. The intensity of photosynthetically active radiation (PAR) above the water surface was measured with a LI-COR quantum sensor (400 to $700 \mathrm{~nm}$ ). PAR was averaged every $10 \mathrm{~min}$ and used for the calculation of daily primary production.

Analytical methods. Samples for analysis of dissolved inorganic nutrients were filtered through a combusted and acid-washed $47 \mathrm{~mm}$ Whatman GF/F glass fibre filter. The dissolved inorganic nutrients were analysed according to Grasshoff et al. (1999). Samples for the analysis of chl a were collected on Whatman GF/F glass fibre filters, extracted in methanol, and quantified in a Turner design fluorometer. Chl $a<2 \mu \mathrm{m}$ was prepared by filtration by gravity through a $2 \mu \mathrm{m}$ polycarbonate filter before filtration through GF/F filters. All analyses were conducted in triplicate.

To count and size PCY and HNF, fixed samples were filtered onto black polycarbonate filters (Millipore, $25 \mathrm{~mm}$ diameter, $0.2 \mu \mathrm{m}$ pore size). A Zeiss Axioplan 2 epifluorescence microscope was used for enumeration and sizing. The epifluorescence microscope was connected to a Power Macintosh computer, and an image processing program (IP Lab) was used for enumeration and sizing of PCY and HNF. When counting PCY, a green waveband excitation filter (520 to $560 \mathrm{~nm}$ ) was used and a minimum of 4 pictures and 200 cells in total were analysed per sample. Frequency of dividing PCY cells (FDC) was counted separately, and a large number of fields were screened to count $>30$ dividing cells. Samples for enumeration of HNF were stained with DAPI (Verity \& Sieracki 1993). HNF were counted by switching between UV and blue excitation to differentiate between autotrophic flagellates and HNF based on autofluorescence. Carbon biomass was calculated using a conversion factor of $0.21\left(\mathrm{pg} \mathrm{C} \mathrm{mm}^{-3}\right)$ for PCY (Booth 1993) and $0.22\left(p g \mathrm{C}^{-3}\right.$ ) for HNF (Børsheim $\&$ Bratbak 1987). Estimation of $\mu$ from FDC was conducted according to Campbell \& Carpenter (1986). As the generation times $(=\ln 2 / \mu)$ were long compared to day-lengths, no circadian rhythms should be expected, and $\mu$ was estimated based on 1 sample per day. Mesozooplankton biomass was estimated according to Vadstein et al. (2004).

Primary production was measured using the ${ }^{14} \mathrm{C}$ technique. For each of the 6 mesocosms, radioactive bicarbonate $\left(\mathrm{H}^{14} \mathrm{CO}_{3}{ }^{-}\right)$was added to 2 light and 1 dark bottle filled with water from the integrated samples. The bottles were incubated outside the mesocosms at $2 \mathrm{~m}$ depth for $4 \mathrm{~h}$. After termination of the incubation, water samples were filtered successively through 20, 2 , 0.8 and $0.2 \mu \mathrm{m}$ filters. Radioactivity on the filters was measured in a scintillation counter (Pacard Tri-Carb 1900). Carbon fixation was converted to daily rates using a light factor: insolation of PAR per day divided by insolation during the incubation period. The majority of PCY were found in the size fraction 0.8 to $2 \mu \mathrm{m}$, as verified by direct counts of the 3 size fractions (104 \pm $22 \% \mathrm{SE}, \mathrm{n}=6$ ). A comparison of primary production based on 24 and $4 \mathrm{~h}$ incubations showed no significant difference (slope: $0.82 \pm 0.31 \mathrm{SE}$ ). For each mesocosm, depth profiles of primary production were obtained with the aim of comparing average primary production of the water column from 0 to $6 \mathrm{~m}$ with primary production at $2 \mathrm{~m}$ depth. Average primary production was $17 \pm 11 \%$ SE higher at $2 \mathrm{~m}$ than that from 0 to $6 \mathrm{~m}$. These comparative experiments revealed that daily primary production could be estimated based on measurements made during $4 \mathrm{~h}$ as described above, and that primary production at $2 \mathrm{~m}$ was representative of the water column from 0 to $6 \mathrm{~m}$. $\mu$ was calculated based on primary production (PP) and biomass of PCY $(B)$ :

$$
\mu=\ln \left[(P P+B) B^{-1}\right]
$$

The grids used to harvest PCY for X-ray microanalyses (XRMA) were prepared with a formvar solution and stabilized by a light carbon coating (Heldal 1993). Water samples were pre-fractionated by filtration through an $8 \mu \mathrm{m}$ polycarbonate filter before cells were harvested directly onto grids by centrifugation (Heldal 
1993). Centrifugation tubes were filled with $15 \mathrm{ml}$ of water samples, and centrifuged at $3940 \times g$ for $20 \mathrm{~min}$ at $6^{\circ} \mathrm{C}$. XRMA were carried out on a JEOL $100 \mathrm{CX}$ electron microscope equipped with a scanned image display and a Tractor Z-MAX 30 energy dispersive spectroscope, supported with a SI (Li) crystal detector and a Norwar window for light-element detection. The microscope was operated in scanning transmission mode at a tilt angle of $38^{\circ}$ and accelerating voltage of $80 \mathrm{kV}$ (Norland et al. 1995). Elements reported here are $\mathrm{C}, \mathrm{N}$, and $\mathrm{P}$ (all elements except hydrogen can be detected when XRMA is executed with the transmission electron microscope [TEM] in scanning mode). PCY cells were identified in the TEM based on shape and size. Subsequently, XRMA data were processed based on a criterion of volume, i.e. cells of volume within the range 0.27 to $4.2 \mu^{3}$ were considered to be PCY. This corresponds to the size spectrum used for chemical analysis and the primary production determination of PCY (0.8 to $2 \mu \mathrm{m}$ ), and is in agreement with the size of the majority of cells measured in the epifluorescence microscope.

Calculations and statistical methods. Specific community predation rates $(P)$ on PCY by HNF, ciliates, and appendicularia were calculated according to Eq. (3), which contains 3 parameters/variables: the selection coefficient (SC), clearance rate (CR), and biomass of the predator $\left(B_{\text {pred }}\right)$ :

$$
P=\mathrm{SC} \times \mathrm{CR} \times B_{\text {pred }}
$$

Predation rates by HNF and appendicularia were estimated using a maximum CR of $0.011 \mathrm{l}(\mu \mathrm{g} \mathrm{C} \mathrm{d})^{-1}$ (Fenchel 1984) and $0.0581(\mu \mathrm{g} \mathrm{C} \mathrm{d})^{-1}$ (H. Stibor unpubl. data) and a SC of 1 and 0.95 (H. Stibor unpubl. data), respectively. The predation rate of ciliates was estimated assuming a Type I functional response, using variables SC and CR. SC was calculated from a sizeselectivity spectrum (Hansen et al. 1994) using a PCY ESD of $1.05 \mu \mathrm{m}$, and calculated individually for 3 sizeclasses of ciliates for each sample. CR was determined for each sample based on the availability of food $\left(F_{;} \mathrm{chl}\right.$ $a<20 \mu \mathrm{m}$ converted to carbon assuming a C:chl $a$ ratio of 64:1, authors' unpubl. data) and assuming a maximum ingestion rate $\left(I_{\max }\right)$ of $3.8 \mathrm{~d}^{-1}$ (Gismervik et al. 1996). If ingestion rates $(I)$ of ciliates were lower than $I_{\max }$, then $\mathrm{CR}$ was assumed to be equal to $\mathrm{CR}_{\max }$. If the ingestion rate was at $I_{\max }$ then CR was estimated as $I_{\max }$ divided by the concentration of available food for ciliates $(F)$. Independent calculation of ingestion for the 3 size groups was chosen for the ciliates because ciliate size distribution varied considerably during the experiment (Vadstein et al. 2004).

In our experimental design, each nutrient addition regime was run with 3 replicates and each copepod concentration with 2 replicates. The factorial design gave more robust conclusions than a design with only 1 experimental factor and traditional replication (Box et al. 1978). The effect of the 2 experimental factors on various variables was tested with 2 -factor ANOVA. When noted, sampling day was used as a covariate to improve power in the analysis. In some cases, 1-way ANOVA was performed, and when appropriate multiple comparison was conducted using the Bonferroni procedure. Unless stated otherwise, $\mathrm{p}<0.05$ was considered significant. All statistical analyses were conducted using SYSTAT version 10.

\section{RESULTS}

\section{Copepod concentration}

The initial copepod concentration gradient spanned a range of 14 to $74 \mathrm{\mu g} \mathrm{C} \mathrm{l}^{-1}$. This range was within the normal range of the system. Copepod concentration, determined from weekly sampling during summer (June to September) for the period 1996 to 2000, was normally in the range of 10 to $115 \mu \mathrm{g} \mathrm{Cl}^{-1}$, with yearly summer averages of 30 to $70 \mu \mathrm{g} \mathrm{C}{ }^{-1}$ (I. Gismervik et al. unpubl. data). The calanoid copepod community consisted of Temora longicornis, Centropages sp., Pseudocalanus elongatus and Acartia longiremis. More than two-thirds of the biomass comprised the genera Temora and Pseudocalanus, which were fairly equal in biomass. In mesocosms with ambient copepod concentrations, the densities of calanoid copepods averaged 16 ind. $^{-1}$. The cyclopoid copepod Oithona similis was present at densities of $<5$ ind. $\mathrm{l}^{-1}$, and non-crustacean zooplankton (mainly bivalve veliger larvae and the polychaete Tomopteris sp.) never exceeded 4 ind. $1^{-1}$.

\section{Dissolved nutrients}

From Day 2, clear differences in concentrations of dissolved inorganic nitrogen (DIN: $\mathrm{NO}_{3}{ }^{-}+\mathrm{NH}_{4}{ }^{+}$) and phosphorus (DIP) were observed between the $\mathrm{N}$ - and H-mesocosms, but initial copepod concentration had no effect (Fig. 2). ANOVA, with time as covariate for DIN and DIP, revealed $p<0.0001$ and $p>0.27$ for nutrient addition and initial copepod concentration, respectively. DIN and DIP were stable and averaged $11 \pm 1 \mu \mathrm{g}$ $\mathrm{N} \mathrm{l}^{-1}$ and $1.9 \pm 0.2 \mu \mathrm{g} \mathrm{Pl}^{-1}$ in the $\mathrm{N}$-mesocosms (comparable to the detection limit of DIP). In contrast, there was a tendency for increasing DIN and DIP over time in the $\mathrm{H}$-mesocosms, with average concentrations of $38 \pm$ $3 \mu \mathrm{g} \mathrm{N}^{-1}$ and $5.8 \pm 0.4 \mu \mathrm{g} \mathrm{P} \mathrm{l}^{-1}$, respectively. The concentration of dissolved silicate (DSi) in the N-mesocosms showed a weak tendency of accumulation, and increased by a factor of 5 throughout the experiment in 

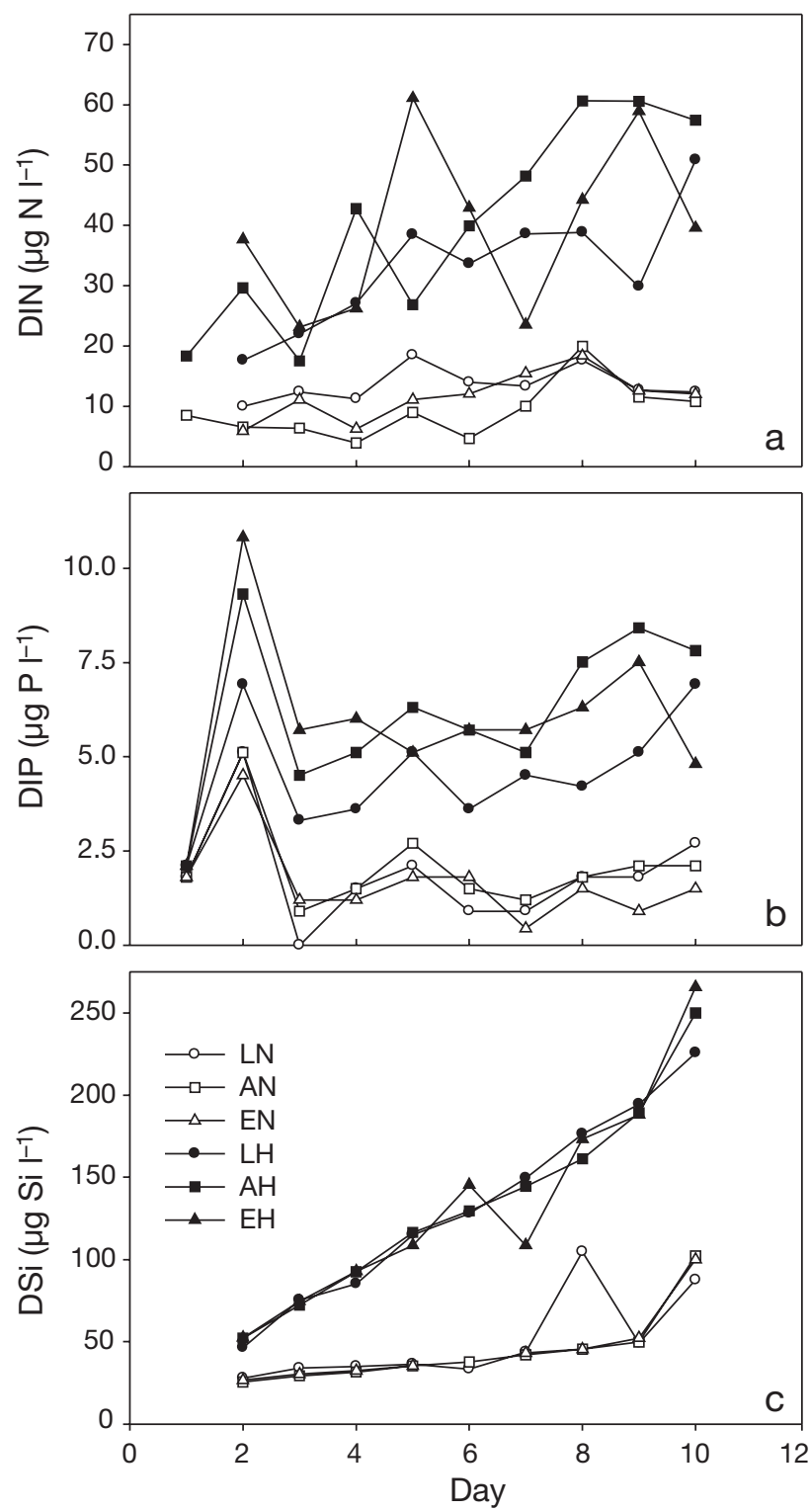

Fig. 2. Time course of concentrations of dissolved (a) inorganic nitrogen (DIN), (b) inorganic phosphorus (DIP) and (c) silicate (DSi). Mesocosm identity: initial copepod concentration, $\mathrm{L}=$ low, $\mathrm{A}=$ ambient, $\mathrm{E}=$ enriched; nutrient addition, $\mathrm{N}=$ normal, $\mathrm{H}=$ high

Table 1. Mean $( \pm \mathrm{SE}) \mathrm{C}$ content, $\mathrm{P}: \mathrm{C}, \mathrm{N}: \mathrm{C}$, and $\mathrm{N}: \mathrm{P}$ ratios of picocyanobacteria (PCY) determined from X-ray-microanalysis. Mesocosm identity as in Fig. 2; $\mathrm{n}=$ no. of analysed cells

\begin{tabular}{|c|c|c|c|c|c|}
\hline Mesocosm & $\begin{array}{c}\mathrm{C} \\
\left(\mathrm{fg} \mathrm{cell}^{-1}\right)\end{array}$ & $\begin{array}{c}\mathrm{P}: \mathrm{C} \\
\left(\mu \mathrm{g} \mathrm{mg}^{-1} \mathrm{C}\right)\end{array}$ & $\begin{array}{c}\mathrm{N}: \mathrm{C} \\
\left(\mu \mathrm{g} \mathrm{mg}{ }^{-1} \mathrm{C}\right)\end{array}$ & $\begin{array}{c}\mathrm{N}: \mathrm{P} \\
\left(\mu \mathrm{g} \mathrm{N} \mu \mathrm{g}^{-1} \mathrm{P}\right)\end{array}$ & $\mathrm{n}$ \\
\hline LN & $101 \pm 28$ & $15 \pm 1$ & $87 \pm 17$ & $7.6 \pm 1.5$ & 32 \\
\hline AN & $78 \pm 12$ & $13 \pm 1$ & $96 \pm 6$ & $10.8 \pm 1.7$ & 44 \\
\hline EN & $57 \pm 5$ & $16 \pm 1$ & $83 \pm 5$ & $8.3 \pm 1.1$ & 59 \\
\hline LH & $52 \pm 4$ & $15 \pm 1$ & $102 \pm 7$ & $11.3 \pm 2.6$ & 38 \\
\hline $\mathrm{AH}$ & $71 \pm 5$ & $13 \pm 1$ & $96 \pm 6$ & $14.4 \pm 2.7$ & 61 \\
\hline $\mathrm{EH}$ & $115 \pm 8$ & $16 \pm 2$ & $86 \pm 3$ & $9.8 \pm 1.8$ & 70 \\
\hline Overall avg. & $79 \pm 4$ & $15 \pm 1$ & $90 \pm 3$ & $8.9 \pm 0.6$ & 304 \\
\hline
\end{tabular}

the H-mesocosms. The rate of increase was $20 \mu \mathrm{g} \mathrm{Si} \mathrm{l}^{-1}$ $\mathrm{d}^{-1}$, which corresponded to $56 \%$ of the daily dose.

\section{Elemental composition of cells}

PCY cells were analysed by XRMA throughout the experiment. As no consistent trends in elemental composition of cells were observed over time, only the average values from the 5 sampling days are presented (Table 1). Average carbon content was in the range of 52 to $115 \mathrm{fg} \mathrm{C} \mathrm{Cell}^{-1}$, with no tendencies with respect to experimental variables (2-factor ANOVA $\mathrm{p}=$ 0.20 and $\mathrm{p}=0.69$ for copepod concentration and nutrient addition, respectively). The average $\mathrm{P}: \mathrm{C}$ ratio for each mesocosm varied from 13 to $16 \mu \mathrm{g} \mathrm{P} \mathrm{mg}{ }^{-1} \mathrm{C}$ (Table 1). The P:C ratio was slightly lower in the Amesocosms compared with other mesocosms (ANOVA $p=0.025$ and $p=0.75$ for copepod concentration and nutrient addition, respectively); a multiple comparison test confirmed the $\mathrm{P}: \mathrm{C}$ ratio in the $\mathrm{A}$-mesocosms to be significantly lower. The average $\mathrm{N}$ : $\mathrm{C}$ ratio varied from 83 to $102 \mu \mathrm{g} \mathrm{N} \mathrm{mg}^{-1} \mathrm{C}$ during the experiment. The N:C ratio tended to be higher in the H-mesocosms $(p=0.12$ and $\mathrm{p}=0.045$ for copepod concentration and nutrient addition, respectively), but multiple comparison revealed no significant differences. The average values of the $\mathrm{N}: \mathrm{P}$ ratio varied from 7.6 to $14.4 \mu \mathrm{g} \mathrm{N} \mathrm{Ng}^{-1} \mathrm{P}$, and a considerably higher cell-to-cell variation was observed for this ratio (Table 1); no significant differences were observed ( $p=0.24$ and $p=0.49$ for copepod concentration and nutrient addition, respectively).

\section{Chl a}

Total chl a (reported by Vadstein et al. 2004) in the $\mathrm{N}$-mesocosms remained relatively constant throughout the experiment ( 1.5 to $3 \mu \mathrm{g} \mathrm{chl} \mathrm{a} \mathrm{l}^{-1}$ ), whereas that in the $\mathrm{H}$-mesocosms showed a steady increase (9 to $12 \mu \mathrm{g}$ chl a $\mathrm{l}^{-1}$ at Day 10). The concentration of copepods did not have any influence on the total chl a concentration (2factor ANOVA $p<0.001$ vs. $p=0.244$ for nutrient addition and copepod concentration, respectively).

Most measurements of chl $a$ in the $<2 \mu \mathrm{m}$ size fraction were in the range of 0.7 to $2.0 \mu \mathrm{g} \mathrm{chl} \mathrm{a} \mathrm{l}^{-1}$ (data not shown), with averages in the range of 1.0 to

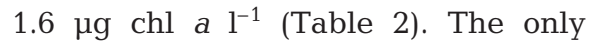
exception was the EH-mesocosm, where chl a concentrations were

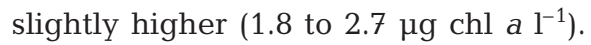
The concentration of chl $a$ in the $<2 \mu \mathrm{m}$ size fraction showed a significant posi- 
Table 2. Mean $( \pm \mathrm{SE})$ PCY biomass, chl $a$ and primary production in the $<2 \mu \mathrm{m}$ size fraction (based on ${ }^{14} \mathrm{C}$-method), specific net rate of change $(r)$, and specific growth rate $(\mu)$ of PCY; 2 estimates of $\mu$ based on frequency of dividing cells ( $\mu_{\text {FDC }}$ ) and a combination of primary production and biomass ( $\mu_{\mathrm{PP}}$ see 'Materials and methods'). Mesocosm identity as in Fig. 2

\begin{tabular}{|c|c|c|c|c|c|c|c|c|}
\hline Mesocosm & $\begin{array}{l}\text { Biomass } \\
\left(\mu \mathrm{C} \mathrm{Cl}^{-1}\right)\end{array}$ & $\begin{array}{l}\text { Chl a } \\
\left(\mu g \mathrm{l}^{-1}\right)\end{array}$ & $\begin{array}{l}<<\mu \mathrm{m} \\
\quad(\% \text { of total })\end{array}$ & $\begin{array}{l}\text { Primary produ } \\
\left(\mu \mathrm{g} \mathrm{Cl}^{-1} \mathrm{~d}^{-1}\right)\end{array}$ & $\begin{array}{l}\text { iction }<2 \mu \mathrm{m} \\
(\% \text { of total) }\end{array}$ & $\begin{array}{c}r \\
\left(\mathrm{~d}^{-1}\right)\end{array}$ & $\begin{array}{l}\mu_{\mathrm{FDC}} \\
\left(\mathrm{d}^{-1}\right)\end{array}$ & $\begin{array}{l}\mu_{\mathrm{PP}} \\
\left(\mathrm{d}^{-1}\right)\end{array}$ \\
\hline LN & $12.0 \pm 1.5$ & $1.04 \pm 0.11$ & $37 \pm 4$ & $6.4 \pm 1.2$ & $23 \pm 2$ & $0.02 \pm 0.19$ & $0.40 \pm 0.26$ & $0.44 \pm 0.09$ \\
\hline AN & $17.8 \pm 1.4$ & $1.17 \pm 0.08$ & $38 \pm 2$ & $8.5 \pm 1.5$ & $27 \pm 2$ & $0.02 \pm 0.11$ & $0.35 \pm 0.14$ & $0.45 \pm 0.09$ \\
\hline EN & $17.0 \pm 1.4$ & $1.39 \pm 0.08$ & $36 \pm 2$ & $12.6 \pm 2.7$ & $32 \pm 5$ & $0.07 \pm 0.10$ & $0.32 \pm 0.10$ & $0.52 \pm 0.09$ \\
\hline LH & $12.7 \pm 1.6$ & $1.36 \pm 0.14$ & $20 \pm 3$ & $11.7 \pm 2.4$ & $17 \pm 3$ & $-0.16 \pm 0.10$ & $0.34 \pm 0.07$ & $0.63 \pm 0.14$ \\
\hline $\mathrm{AH}$ & $17.3 \pm 1.7$ & $1.58 \pm 0.15$ & $29 \pm 4$ & $17.0 \pm 4.6$ & $22 \pm 4$ & $-0.05 \pm 0.12$ & $0.30 \pm 0.12$ & $0.67 \pm 0.12$ \\
\hline EH & $20.3 \pm 1.2$ & $2.27 \pm 0.18$ & $31 \pm 3$ & $28.6 \pm 9.6$ & $29 \pm 5$ & $-0.00 \pm 0.10$ & $0.33 \pm 0.19$ & $0.74 \pm 0.09$ \\
\hline
\end{tabular}

tive response to both the dose of nutrients added and initial copepod concentration (ANOVA with Day as covariate, $\mathrm{p}<0.0001$ for both). For all N-mesocosms and the LH-mesocosm, there was a significant reduction in chl $a$ in the $<2 \mu \mathrm{m}$ size fraction over time $(\mathrm{p}<$ 0.02), whereas no trends were observed in the other $\mathrm{H}$ mesocosms $(\mathrm{p}>0.18)$. The picoplankton $(<2 \mu \mathrm{m})$ contributed a larger percentage to total chl $a$ in the $\mathrm{N}$ mesocosms than in the H-mesocosms (Table 2).

\section{Biomass and population growth of picocyanobacteria}

The cell numbers of PCY varied from 6.0 to $18 \times 10^{7}$ cells $\mathrm{l}^{-1}$ during the experiment, and showed trends similar to those of carbon biomass (Fig. 3). PCY biomass decreased throughout the experiment to $\sim 10 \mu \mathrm{g}$ $\mathrm{C}^{-1}$ in the L-mesocosms (low copepod concentration). In the other mesocosms, PCY biomass showed some fluctuations, but remained relatively stable within the

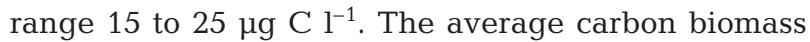
in both the $\mathrm{H}$ - and $\mathrm{N}$-mesocosms increased with an increase in copepod concentration, but nutrient addition had no effect (ANOVA $p=0.0001$ and $p=0.237$, respectively; Table 2). Multiple comparison via 1-way ANOVA confirmed that PCY biomass was significantly lower in L-mesocosms under both nutrient regimes. The specific net rate of change of PCY (r, Eq. 1) was not statistically different from zero in N-mesocosms (Table 2). In H-mesocosms, $r$ was negative, but again values were not statistically different from zero except in the case of the LH-mesocosm, which showed a significant decrease in PCY biomass.

\section{Primary production and specific growth rate}

The ${ }^{14} \mathrm{C}$-based autotrophic picoplankton production in N-mesocosms was at a relatively constant level, whereas production was clearly higher in H-mesocosms, and there was a tendency for an increase on Day 10 (data not shown). The average autotrophic

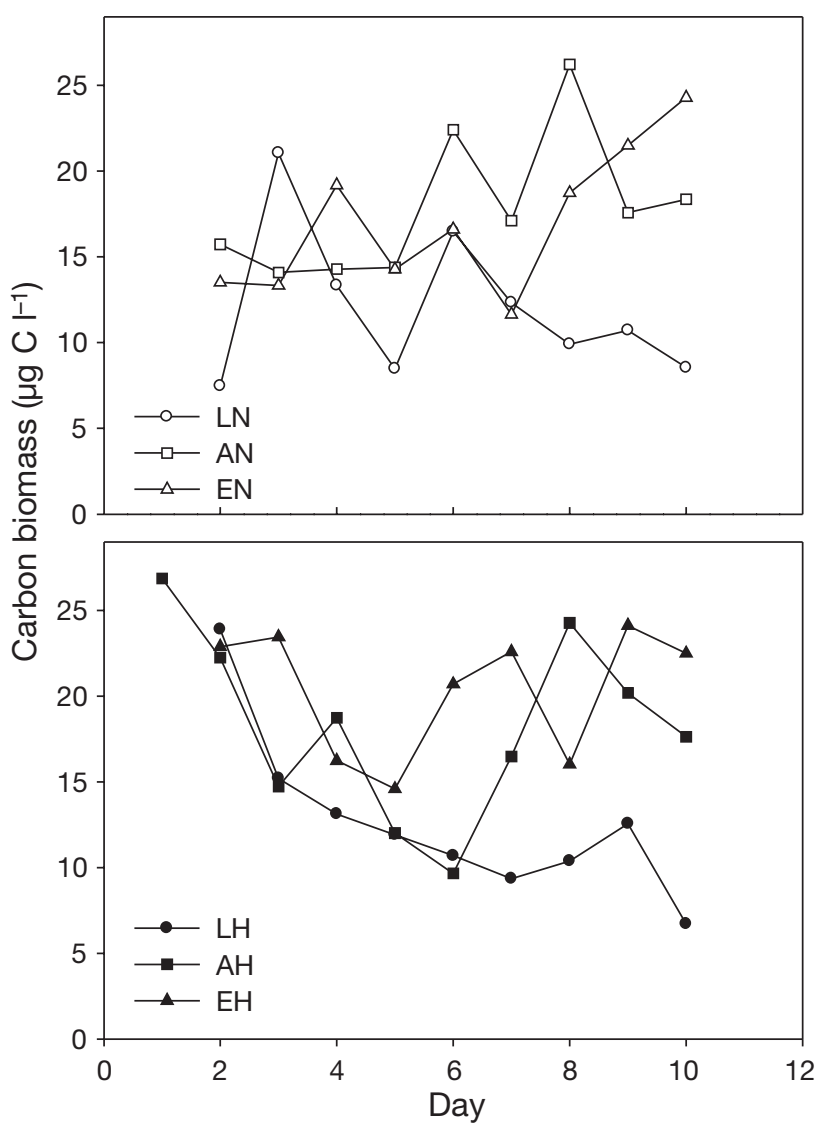

Fig. 3. Time course of carbon biomass of PCY. Mesocosm identity as in Fig. 2

picoplankton production for the $10 \mathrm{~d}$ period ranged from 6.4 to 12.6 and 11.7 to $28.6 \mu \mathrm{g} \mathrm{C}^{-1} \mathrm{~d}^{-1}$ for $\mathrm{N}$ - and $\mathrm{H}$-mesocosms, respectively (Table 2), and the effect of nutrient addition on primary production of picoplankton was statistically significant ( $p=0.013$ ). However, the response was considerably higher for phytoplankton in the $>2 \mu \mathrm{m}$ size fraction. For both $\mathrm{N}$ - and H-mesocoms, picoplankton production increased with increasing initial copepod concentration, and this difference was marginally significant $(p=0.052)$. Picoplankton production constituted a larger part of total 
primary production in N-mesocosms ( 23 to $32 \%$ ) than in H-mesocosms (17 to $29 \%$; Table 2).

PCY $\mu$ was calculated from primary production and biomass measurements $\left(\mu_{\mathrm{PP}}\right)$, and the frequency of dividing cells (FDC; $\mu_{\mathrm{FDC}}$ ) (Fig. 4). FDC values were in the range of 2 to $8 \%$ during the beginning of the experiment, but stabilized around 4 to $5 \%$ in the second half of the experiment (data not shown). Mean $\mu_{\mathrm{PP}}$ was always higher than mean $\mu_{\mathrm{FDC}}$ (Table 2), but the 2 estimates of $\mu$ tended to show a similar trend over time (Fig. 4). Average $\mu_{\mathrm{FDC}}$ ranged from 0.30 to $0.40 \mathrm{~d}^{-1}$, whereas average $\mu_{\mathrm{PP}}$ ranged from 0.44 to $0.74 \mathrm{~d}^{-1}$ (Table 2). The $\mu_{\mathrm{PP}}$ was somewhat higher in H-mesocosms than in $\mathrm{N}$-mesocosms. The E-mesocosms had higher $\mu_{\mathrm{PP}}$ than did A-mesocosms. However, as the day-to-day variation was large, $\mu_{\mathrm{PP}}$ did not differ significantly among mesocosms, with the exception of the EH-mesocosm. The calculated $\mu_{\text {FDC }}$ values were neither affected by nutrient supply rate nor by copepod concentration $(p>0.46$; Table 2). In addition to PCY, eukaryotic picoplankton also contributed to the ${ }^{14} \mathrm{C}$-based primary production in the 0.8 to $2 \mu \mathrm{m}$ size fraction; thus, PCY activity was overestimated to a variable extent. A clear increase (not quantified) in eukaryotic picoplankton was observed towards the end of the experiment in several of the mesocosms.

\section{Predators and predation}

Average biomass of ciliates and appendicularia exhibited an inverse relationship with initial copepod concentration and a positive relationship with nutrient addition (Table 3). The average biomass of HNF showed an opposite trend: it increased slightly with increasing initial copepod concentration, but did not respond to enhanced nutrient supply. Statistical analysis revealed significant differences only for ciliates $(p=$ 0.006 and 0.001 for nutrients and initial copepod concentration, respectively). The effects on appendicularia were statistically significant over a longer time scale (Stibor et al. 2004a). Vadstein et al. (2004) and Stibor et al. (2004a) discussed in more detail (respectively) ciliate and appendicularia development during the experiment.

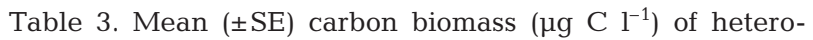
trophic nanoflagellates (HNF), ciliates, and appendicularia

\begin{tabular}{|lccc|}
\hline Mesocosm & HNF & Ciliates & Appendicularia \\
\hline LN & $4.3 \pm 1.8$ & $28 \pm 6$ & $42.3 \pm 35.7$ \\
AN & $6.5 \pm 2.5$ & $15 \pm 2$ & $11.0 \pm 7.0$ \\
EN & $7.7 \pm 2.6$ & $14 \pm 2$ & $1.8 \pm 1.0$ \\
LH & $4.7 \pm 1.7$ & $38 \pm 8$ & $21.0 \pm 15.7$ \\
AH & $4.6 \pm 1.2$ & $33 \pm 7$ & $4.3 \pm 1.1$ \\
EH & $6.2 \pm 1.5$ & $16 \pm 4$ & $2.5 \pm 1.7$ \\
\hline
\end{tabular}

The predation rate of HNF on PCY decreased steadily throughout the mesocosm experiment (Fig. 5), with the exception of the E-mesocosms: in these mesocosms, HNF exhibited the highest predation rates on PCY towards the end of the experiment. The predation rates of ciliates on $\mathrm{PCY}$ increased in all mesocosms during the experiment, but rates were lower in Emesocosms than in L- and A-mesocosms. Generally, the largest size group of ciliates did not contribute to estimated predation rates. The predation rates of appendicularia on PCY reached the highest levels in Lmesocosms and in the AN-mesocosm, but stayed low 


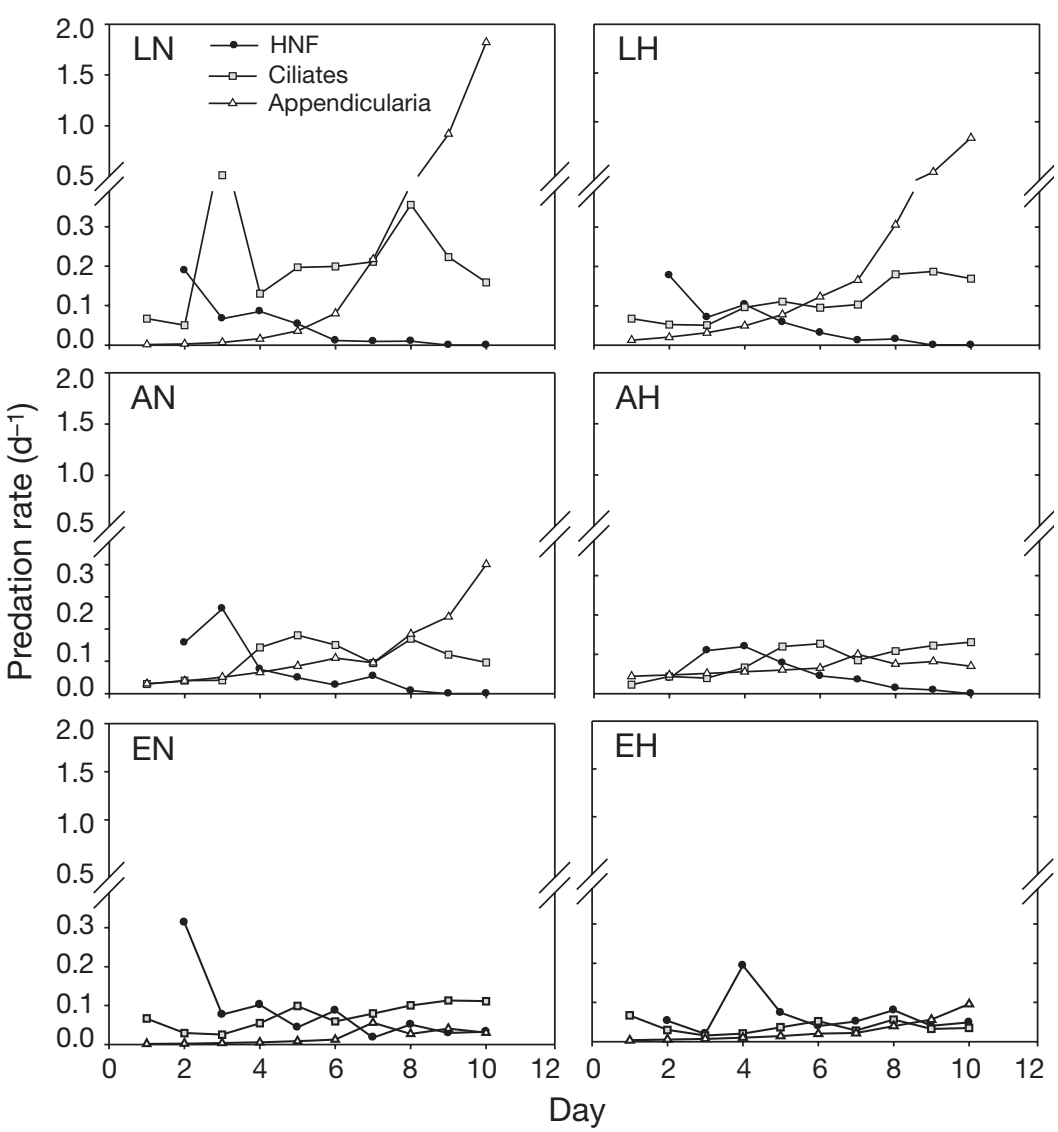

Fig. 5. Time course of predation rates by heterotrophic nanoflagellates (HNF), ciliates, and appendicularia on PCY. Mesocosm identity as in Fig. 2
(Table 4). Accordingly, total predation pressure on PCY decreased with increasing initial copepod concentration for both nutrient addition regimes. Furthermore, total predation pressure on PCY was 25 to $38 \%$ lower in $\mathrm{H}$ mesocosms compared with N-mesocosms. Thus, nutrient addition resulted in slightly lower predation pressure on PCY. ANOVA, with time as covariate, confirmed a significant negative effect of copepod concentration ( $p=0.0001$ ) and nutrient addition $(p=0.048)$ on predation rates.

Estimated mortality rates $\left(m=\mu-r_{i}\right.$ Eq. 1) were higher than predation rates in all mesocosms except the LN-mesocosm (Table 4). However, in most cases, overall mortality and predation were not significantly different, i.e. residual mortality $(\mu-r-p=m-p$, where $p$ is sum of predation) was not significantly different from zero. Therefore, sources of PCY mortality other than predation are not strictly required to account for our observations. However, the fact that average mortality was higher than predation in 5 out of 6 mesocosms (positive residual mortality) and that errors are large in residual mortality (Table 4) suggest that other processes may have caused mortality of PCY.

in the remainder. The predation rate of ciliates and appendicularia on PCY showed an overall increase during the experiment in all mesocosms, and predation rates were highest in L-mesocosms (Fig. 5). On Day 10, the predation rates of appendicularia reached maximum values of 1.9 and $0.8 \mathrm{~d}^{-1}$ in the LN- and LHmesocosms, respectively.

Total average predation pressure on PCY was highest in L-mesocosms and lowest in E-mesocosms

Table 4. Mean $( \pm \mathrm{SE})$ predation rate $\left(\mathrm{d}^{-1}\right)$ by HNF, ciliates, and appendicularia, and residual mortality of PCY. Residual mortality is calculated as $\mu-r-p=m-p$, where $r$ is specific net rate of change, $p$ is sum predation and $m$ is total mortality

\begin{tabular}{|lccccr|}
\hline Mesocosm & HNF & Ciliates & Appendicularia & $\begin{array}{c}\text { Sum } \\
\text { predation }\end{array}$ & $\begin{array}{c}\text { Residual } \\
\text { mortality }\end{array}$ \\
\hline LN & $0.05 \pm 0.02$ & $0.16 \pm 0.03$ & $0.68 \pm 0.19$ & $0.60 \pm 0.01$ & $-0.27 \pm 0.22$ \\
AN & $0.07 \pm 0.03$ & $0.11 \pm 0.02$ & $0.18 \pm 0.04$ & $0.30 \pm 0.02$ & $0.08 \pm 0.07$ \\
EN & $0.08 \pm 0.03$ & $0.07 \pm 0.01$ & $0.03 \pm 0.01$ & $0.17 \pm 0.02$ & $0.07 \pm 0.09$ \\
LH & $0.06 \pm 0.02$ & $0.11 \pm 0.02$ & $0.34 \pm 0.08$ & $0.37 \pm 0.05$ & $0.08 \pm 0.13$ \\
AH & $0.05 \pm 0.01$ & $0.09 \pm 0.01$ & $0.07 \pm 0.01$ & $0.20 \pm 0.01$ & $0.16 \pm 0.13$ \\
EH & $0.07 \pm 0.02$ & $0.03 \pm 0.01$ & $0.04 \pm 0.01$ & $0.13 \pm 0.02$ & $0.20 \pm 0.09$ \\
\hline
\end{tabular}

\section{Synthesis of effects of nutrient supply and predation on picocyanobacteria}

Results averaged over time tend to lead to conservative conclusions about the effects of experimental factors, as some time was required for the plankton communities to adapt to the gradients of experimental factors. Fig. 6 summarizes the average effects of nutrient supply and copepod concentration on biomass and growth rate of PCY from Days 6 to 10, in addition to interactions with predators feeding on PCY. A 2-factor ANOVA with time as covariate revealed that PCY biomass responded positively to an increase in initial copepod concentration $(\mathrm{p}<0.0001)$, whereas neither nutrient addition $(p=0.695)$ nor time as covariate $(p=0.515)$ had any effect (Fig. 6A). In total, a $2 \times$ variation in average biomass was observed. During this 


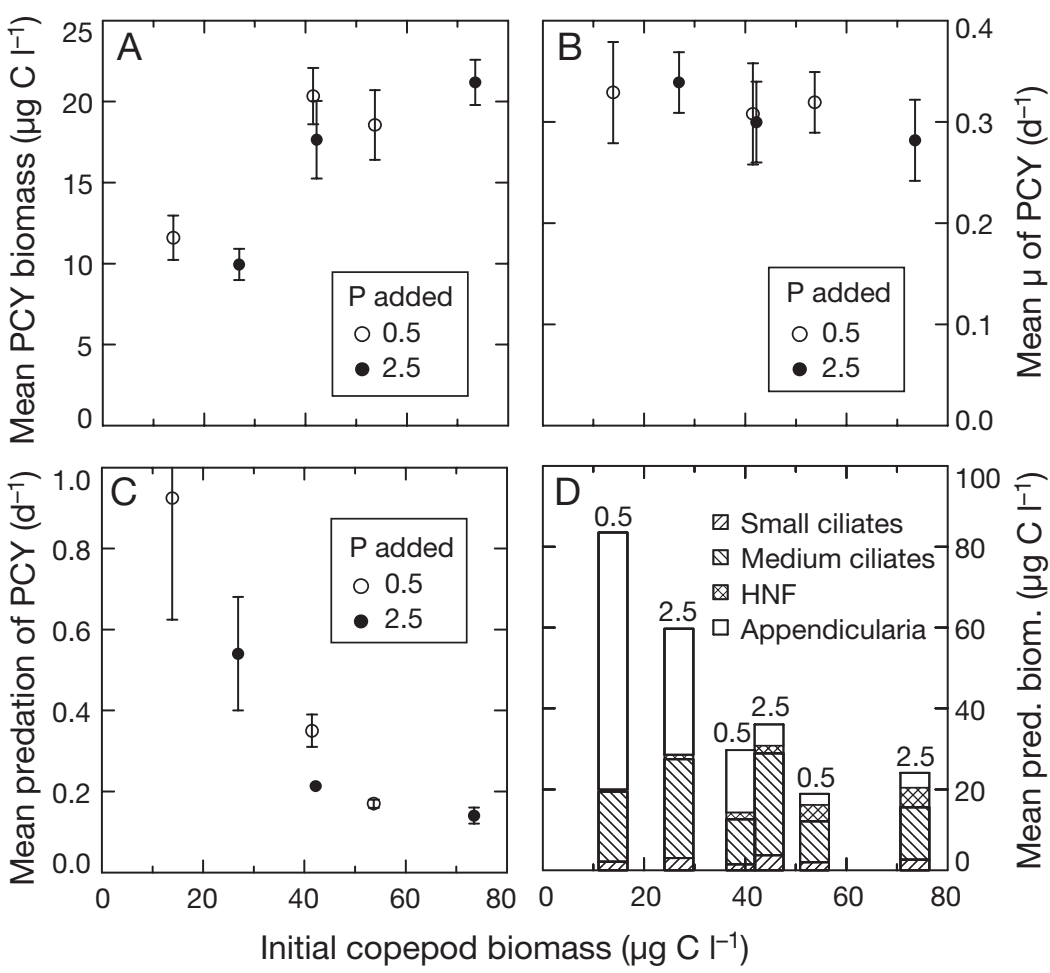

Fig. 6. (A) mean PCY biomass, (B) mean $\mu$ of PCY, (C) mean predation rates on PCY, and (D) mean biomass of predators feeding on PCY plotted against initial copepod concentration from Days 6 to 10. Nutrient addition regime (0.5 and $2.5 \mathrm{mg} \mathrm{P} \mathrm{m}^{-3} \mathrm{~d}^{-1}$ ) indicated in each panel (see top of bars in panel D). (D) Largest size-group of ciliates not included (see 'Results'); initial copepod concentration adjusted for the 2 intermediate copepod densities to avoid overlap of bars

period, mean $\mu$ of PCY was not affected by the experimental variables (Fig. 6B; ANOVA $\mathrm{p}>0.63$ ).

The mean predation rate on PCY (Fig. 6C) was strongly and inversely related to initial copepod concentration (ANOVA, $p=0.0001$ and $p=0.063$ for initial copepod concentration and nutrient addition, respectively). Time was a significant covariate $(\mathrm{p}=$ 0.003), which is evident from the time-course of predation (Fig. 5). In both L-mesocosms, predation increased by a factor of 4 over time. Average predation estimates for the period varied by a factor of 6 . Our predation estimates were based on determinations of predator biomass and literature values on clearance rates, and therefore entail some uncertainty. However, the strong negative effect of copepod concentration on the biomass of predators of PCY (Fig. 6D) revealed that the effect of predation must have been lessened with increasing initial copepod biomass. However, although increasing copepod concentration resulted in decreases in the biomass of appendicularia and ciliates by factors of 10 and 2, respectively, a 10-fold increase in HNF was observed.

\section{DISCUSSION}

\section{Biomass and growth rates of picocyanobacteria}

Very few data on picoplankton biomass from northern temperate marine waters are published (Hopavågen is $\left.63^{\circ} 36^{\prime} \mathrm{N}\right)$. In a previous study conducted in Hopavågen (Olsen et al. 2006), PCY biomass was recorded to be 2 to 4 times higher than the average biomasses observed in the present study. However, typical biomass of PCY in Hopavågen is 20 to $50 \mu \mathrm{C} \mathrm{l}^{-1}$ in August/September, and lower earlier in summer (O. Vadstein unpubl. data).

Net rates of change ( $r_{i}$ Eq. 1$)$ of PCY were not statistically different from zero (Table 2). Net changes in PCY biomass were also found by others to be low, despite growth rates in the order of 1 division per day (Liu et al. 1995, Olsen et al. 2006).

$\mu$ in our study were lower than those reported by Affronti \& Marshall (1994), but in agreement with the average specific growth rate of $0.41 \mathrm{~d}^{-1}$ found by Lavallée \& Pick (2002). Most literature values of $\mu$ are from temperate and subtropical regions, where average sea temperatures are higher than $12^{\circ} \mathrm{C}$ (ambient temperature during the present study). In our experiment, values of $\mu$ fall within the typical range compiled by Agawin et al. (1998) for similar temperatures.

\section{Growth limiting factors - bottom-up control}

Potential factors limiting growth of PCY were evaluated based on the concentration of DIP and DIN and the elemental composition ( $\mathrm{P}, \mathrm{N}$, and $\mathrm{C}$ ) of PCY cells. DIN and DIP accumulated, and were clearly in excess in $\mathrm{H}$-mesocosms. Concentrations in N-mesocosms were more difficult to judge, as the DIP concentrations were close to the detection limit of our methods. PCY can grow at high rates with DIN concentrations $<14 \mu \mathrm{N} \mathrm{N}^{-1}(<1 \mu \mathrm{M}$; Agawin et al. 2000), and ambient phosphate levels as low as $0.5 \mathrm{nM}\left(0.16 \mu \mathrm{g} \mathrm{P} \mathrm{l}^{-1}\right)$ could support growth of Synechococcus spp. at a rate of 1 division per day (Ikeya et al. 1997). Some experiments indicated that Synechococcus spp. primarily uses regenerated nitrogen (Lindell \& Post 2001). However, there are strong indications that Synechococcus spp. (as opposed to Prochlorococcus spp.) can utilise 
nitrate as a sole source of N (Scanlan \& West 2002). Moreover, half of the added $\mathrm{N}$ was in the form of ammonia, and average ammonium concentrations during the period from Days 5 to 10 ranged from 9 to 10 and 14 to $22 \mu \mathrm{g} \mathrm{N}^{-1}$ in $\mathrm{N}$ - and $\mathrm{H}$-mesocosms, respectively (data not shown). Thus, even ammonia levels were high enough to support high growth rates, at least in H-mesocoms.

Cell quotas based on XRMA showed that the average $\mathrm{N}$ : $\mathrm{C}$ ratio did not vary significantly among mesocosms, and averaged $90 \pm 3 \mu \mathrm{g} \mathrm{N} \mathrm{mg}^{-1} \mathrm{C}$ (Table 1). The average $\mathrm{P}: \mathrm{C}$ ratio was $15 \pm 1 \mu \mathrm{g} \mathrm{P} \mathrm{mg}^{-1} \mathrm{C}$. Although a significantly lower $\mathrm{P}$ content was observed in A-mesocosms, this $15 \%$ difference was so small that it must have been of limited biological significance. This limited significance is due to the fact that $\mathrm{P}$ content was high compared with the minimum $\mathrm{P}$ content required for growth, and also because of the asymptotic relationship between $\mu$ and cell quota proposed by the Droop model (Vadstein 2000). The fact that no significant differences were observed between $\mathrm{N}$ - and H-mesocosms in neither elemental composition (N:C and $\mathrm{P}: \mathrm{C}$ ) nor in $\mu$ strongly indicates (1) similar PCY physiology among mesocosms, and (2) sufficient DIN and DIP in all mesocosms throughout the experiment. Recent culture studies on $\mathrm{N}$ and $\mathrm{P}$ content of Synechococcus spp. indicate that N:C and P:C ratios of exponentially growing cells are in the range

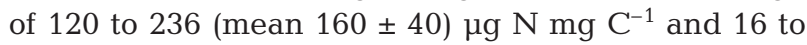

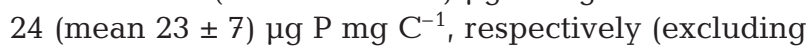
one low P:C ratio; Bertilsson et al. 2003, Heldal et al. 2003). The averages observed in our study were 35 to $45 \%$ lower than those cited above. However, temperatures used in these previous culture studies were 5 to $10^{\circ} \mathrm{C}$ above temperatures used in our experiments, which results in higher maximum growth rates. Both the $\mathrm{N}$ and especially the $\mathrm{P}$ content should increase with increasing growth rates due to higher RNA content.

We conclude that our data on concentrations of inorganic nutrients, elemental composition of cells, and $\mu$ were consistent among all experimental units. These data indicate that physiology of PCY was similar among all mesocosms. Moreover, as $\mu$ did not differ significantly among mesocosms, we conclude that $\mu$ of PCY were at, or close to, their $\mu_{\max }\left(0.34 \mathrm{~d}^{-1}\right)$ during the experiment. As a consequence, PCY did not experience more than very moderate nutrient limitation (bottom-up control).

\section{Loss rates - top-down control}

As the $\mu$ of PCY was high in all mesocosms and net growth rate $(r)$ did not differ significantly from zero
(Table 2), substantial losses must have occurred. We did not observe aggregation of PCY or attachment to particles, thus predation and virus infections are the two most likely processes (Fig. 1). In contrast to the biomass of PCY, the biomass of appendicularia and ciliates decreased with increasing initial copepod concentration (Table 3). As a consequence, the predation rates of these 2 groups on PCY were inversely related to copepod concentration (Fig. 6, Table 4).

Our results suggest that ciliates and appendicularia were the main predators of PCY, especially in L-mesocosms. In mesocosms with a high initial copepod concentration (H-mesocosms), HNF exhibited a slightly higher predation rate on PCY than did appendicularia or ciliates (Table 4). The reason for this shift was most likely the difference in predation pressure exerted by copepods on the different groups of organisms preying on PCY. Although ciliates are directly preyed upon by copepods (cf. Gismervik et al. 1996), the most significant predators of HNF ( 2 to $6 \mu \mathrm{m}$ ) are ciliates and appendicularia (Hansen et al. 1994). The relationship between appendicularia and copepods is not clear, and there is little literature on the subject. However, the biomass of appendicularia was very low in mesocosms with an abundant biomass of copepods, which could have been due to predation on young stages of appendicularia by copepods (Stibor et al. 2004a). The decrease in HNF biomass in all mesocosms suggests that they were heavily preyed upon by ciliates and appendicularia. Jürgens et al. (1999) reported similar results, with low predation rates on HNF by copepods, and reduced total predation pressure on HNF owing to efficient predation of copepods on ciliates. Therefore, we conclude that predation was the most important process controlling PCY biomass. Furthermore, we postulate that as PCY are preyed upon by organisms that differ considerably in size (ciliates vs. HNF), it is unlikely that they escape heavy predation due to changes in the structure at higher trophic levels and thus strength in the trophic cascade mediated down to PCY.

Our data suggest that predation could account for a large proportion of the mortality required to balance the PCY budget (Eq. 2). In fact, residual mortality (see Table 4) was not significantly different from zero. However, residual mortality was positive in 5 out of 6 mesocosms, and ranged between 22 and $61 \%$ of $\mu$ (average $37 \%$ ) (Tables $2 \& 4$ ). Thus, it is reasonable to assume that, e.g., viral-induced mortality of PCY could have been significant, even though our data are clearly not conclusive. Previous studies suggested a variable significance of cyanophage-induced mortality of PCY (Ortman et al. 2002), and that PCY communities may be dominated by cells resistant to co-occurring phages (Waterbury \& Valois 1993). 


\section{CONCLUSIONS}

We conclude that PCY biomass in the mesocosms was regulated by top-down control. The top predators in this planktonic food web - the copepods - exerted a cascading effect by limiting abundances of the dominant predators of PCY (Carpenter et al. 1985). Thus, copepods indirectly controlled abundances of PCY. We will not generalize our conclusions on top-down control, because the dominant predators of PCY interact in other ways than competition for prey. For example, both ciliates and appendicularia feed on HNF, and the size of predatory copepods structure the ciliate community and consequently influence the fraction of ciliates able to prey on PCY. Moreover, copepods may act as a switch between alternating trophic cascades (Stibor et al. 2004b), and the strength of the trophic cascade down to PCY will therefore depend on the structure of the food web and the species inventory of copepods (Gismervik 2006). The addition of nutrients did not have a noticeable direct affect on PYC; thus, there were no bottom-up effects. However, the supply of nutrients had an indirect effect through the build-up of predator biomass (ciliates), owing to an increase in the food supply available to these predators.

Acknowledgements. This study was funded by the Research Council of Norway (Contract 127176/120: 'The Hopavågen fertilization experiment'; and Contract 143184/140: CALANUS, a Strategic Research Program at NTNU) and by the EU Commission through Trondheim Marine Systems Research Infrastructure and Project EVK3-CT-2000-00034 DOMAINE (awarded to F. Thingstad). We acknowledge K. Løset from Trondhjem Biological Station for providing sizeclass data for ciliate biomass. We thank K. Andresen, S. Linde, N. Tokle and $\varnothing$. Leiknes from Trondhjem Biological Station for technical assistance, J. Værnes for catering, E. Erichsen, Laboratory for Electron Microscopy, University of Bergen, and S. Nordland, Department of Microbiology, University of Bergen for contributions to XRMA analysis. The paper benefited from the comments of 3 anonymous reviewers.

\section{LITERATURE CITED}

Affronti LF, Marshall HG (1994) Diel abundance and productivity patterns of autotrophic picoplankton in the lower Chesapeake Bay. J Plankton Res 15:1-8

Agawin NSR, Duarte CM, Augusti S (1998) Growth and abundance of Synechococcus sp. in a Mediteranean Bay: seasonality and relationship with temperature. Mar Ecol Prog Ser 170:45-53

Agawin NSR, Duarte CM, Augusti S (2000) Nutrient and temperature control of the contribution of picoplankton to phytoplankton biomass and production. Limnol Oceanogr 45:591-600

Bertilsson S, Berglund O, Karl DM, Chisholm SW (2003) Elemental composition of marine Prochlorococcus and Synechococcus: implications for the ecological stoichiometry of the sea. Limnol Oceanogr 48:1721-1731
Booth BC (1993) Estimating cell concentration and biomass of autotrophic plankton using microscopy. In Kemp PF, Sherr BF, Sherr EB, Cole JJ (eds) Handbook of methods in aquatic microbial ecology. Lewis Publishers, Boca Raton, FL, p 199-205

Børsheim Y, Bratbak G (1987) Cell-volume to cell carbon conversion factors for a bacterivorous Monas sp. enriched from seawater. Mar Ecol Prog Ser 36:171-175

Box GEP, Hunter WG, Hunter JS (1978) Statistics for experimenters: an introduction to design, data analysis, and model building. Wiley Interscience, New York

Campbell L, Carpenter EJ (1986) Diel patterns of cell division in marine Synechococcus spp.: use of the frequency of dividing cells technique to measure growth rate. Mar Ecol Prog Ser 32:139-148

Carpenter SR, Kitchell JF, Hodgson JR (1985) Cascading trophic interactions and lake productivty. BioScience 35:634-639

Christaki U, Jacquet S, Dolan J, Valout D, Rassoulzadegan F (1999) Growth and grazing on Procholrococcus and Synechococcus by two marine ciliates. Limnol Oceanogr 44: $52-61$

Dolan JR, Šimek K (1999) Diel periodicity in Synechococcus populations and grazing by heterotrophic nanoflagellates: analysis of food vacuole contents. Limnol Oceanogr 44: 1565-1570

Fenchel T (1984) Ecology of heterotrophic microflagellates. 2. Bioenergetics and growth. Mar Ecol Prog Ser 8:225-231

Flood PR (1978) Filter characteristics of appendicularian food catching nets. Experientia 34:173-175

Gismervik I (2006) Top-down impact by copepods on ciliate numbers and persistence depends on copepod and ciliate species composition. J Plankton Res 28:499-507

Gismervik I, Andersen T, Vadstein O (1996) Pelagic food webs and eutrophication of coastal waters: impact of grazers on algal communities. Mar Pollut Bull 33:22-35

Grasshoff K, Kremling K, Ehrhardt M, Anderson LG (1999)

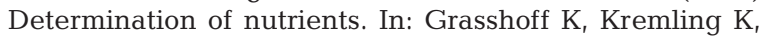
Ehrhardt M (eds) Methods of seawater analysis. Wiley$\mathrm{VCH}$, Weinheim, p 159-226

Hansen B, Bjørnsen PK, Hansen PJ (1994) The size ratio between planktonic predators and their prey. Limnol Oceanogr 39:395-403

Heldal M (1993) Measurement of elemental content and dry weight of single cells: X-ray microanalysis. In: Kemp PF, Sherr BF, Sherr EB, Cole JJ (eds) Handbook of methods in aquatic microbial ecology. Lewis Publishers, Boca Raton, FL, p 387-394

Heldal M, Scanlan DJ, Norland S, Thingstad F, Mann NH (2003) Elemental composition of single cells of various strains of marine Prochlorococcus and Synechococcus using X-ray microanalysis. Limnol Oceanogr 48: $1732-1743$

Ikeya T, Ohki K, Takahasi M, Fujita Y (1997) Study on phosphate uptake of the marine cyanophyte Synechococcus sp. NIBB 1071 in relation to oligotrophic environments in the open ocean. Mar Biol 129:195-202

Johnson PW, Sieburth JMN (1979) Chroccoid cyanobacteria in the sea: a ubiquitous and diverse phototrophic biomass. Limnol Oceanogr 24:928-935

Jürgens K, Wickham SA, Rothhaupt KO, Santer B (1999) Feeding rates of macro- and microzooplankton on heterotrophic nanoflagellates. Limnol Oceanogr 41:1833-1839

Lavallée BF, Pick FR (2002) Picocyanobacteria abundance in relation to growth and loss rates in oligotrophic to mesotrophic lakes. Aquat Microb Ecol 27:37-46

Lindell D, Post AF (2001) Ecological aspects of ntcA expression and its use as an indicator of the nitrogen status of 
marine Synechococcus spp. Appl Environ Microbiol 67: 3340-3349

Liu H, Campbell L, Landry MR (1995) Growth and mortality rates of Prochlorococcus and Synechococcus measured with a selective inhibitor technique. Mar Ecol Prog Ser 116:227-287

Lu J, Chen F, Hodson RE (2001) Distribution, isolation, host specificity, and diversity of cyanophages infecting marine Synechococcus spp. in river estuaries. Appl Environ Microbiol 67:3285-3290

Moutin T, Thingstad TF, Wambeke F, Marie D, Slawyk G, Raimbaul P, Claustre H (2002) Does competition for nanomolar phosphate supply explain the predominance of the cyanobacterium Synechococcus? Limnol Oceanogr 40: $1077-1090$

Nakamura Y, Suzuki K, Suzuki SY, Hiromi J (1997) Production of Oikopleura dioica (Appendicularia) following a picoplankton 'bloom' in a eutrophic coastal area. J Plankton Res 19:113-124

Norland S, Fagerbakke KM, Heldal M (1995) Light element analysis of individual bacteria using X-ray microanalysis. Appl Environ Microbiol 61:1357-1362

Olsen Y, Agusti S, Andersen T, Duarte CM and 13 others (2006) A comparative study of responses in nutrient pools and plankton food web structure and function in contrasting European coastal waters exposed to experimental nutrient addition. Limnol Oceanogr 51:488-503

Ortmann AC, Lawrence JE, Suttle CA (2002) Lysogeny and lytic viral production during a bloom of the cyanobacterium Synechococcus spp. Microb Ecol 43:225-231

Raven JA (1986) Physiological consequences of extremely size for autotrophic organisms in the sea. Can Bull Fish Aquat Sci 214:1-70

Scanlan DJ, West NY (2002) Molecular ecology of the marine cyanobacterial genera Prochlorococcus and Synechococcus. FEMS Microbiol Ecol 40:1-12

Šimek K, Macek M, Pernthaler J, Straskrabova V, Psenner R (1996) Can freshwater ciliates survive on a diet of picoplankton? J Plankton Res 18:597-613

Editorial responsibility: Klaus Jürgens,

Rostock, Germany
Stibor H, Vadstein O, Lippert B, Roederer W, Olsen Y (2004a) Calanoid copepods and nutrient enrichment determine appendicularian Oikopleura dioica population dynamics in a mesocosm experiment. Mar Ecol Prog Ser 270: 209-215

Stibor H, Vadstein O, Diel S, Gelzleichter A and 10 others (2004b) Copepods act as a switch between alternative trophic cascades in marine pelagic food webs. Ecol Lett 7 : 321-328

Stockner JG (1988) Phototrophic picoplankton: an overview from marine and freshwater ecosystems. Limnol Oceanogr $4: 765-775$

Vadstein O (2000) Heterotrophic, planktonic bacteria and cycling of phosphorus: phosphorus requirements, competitive ability and food web interactions. Adv Microb Ecol 16:115-168

Vadstein O, Stibor H, Lippert B, Løseth K, Roederer W, Sundt-Hansen L, Olsen Y (2004) Moderate increase in the biomass of omnivorous copepods may release grazing control of planktonic algae. Mar Ecol Prog Ser 270: 199-207

Verity PG, Sieracki ME (1993) Use of colour image analysis and epifluorescence microscopy to measure plankton biomass. In: Kemp PF, Sherr BF, Sherr EB, Cole JJ (eds) Handbook of methods in aquatic microbial ecology. Lewis Publishers, Boca Raton, FL, p 327-337

Waite AM, Safi KA, Hall J, Nodder SD (2000) Mass sedimentation of picoplankton embedded in organic aggregates. Limnol Oceanogr 45:87-97

Waterbury JB, Valois FW (1993) Resistance to co-occurring phages enables marine Synechoccus communities to coexist with cyanophages abundant in seawater. Appl Environ Microbiol 59:3393-3399

Waterbury JB, Watson S, Guillard RRL, Brand LE (1979) Widespread occurrence of a unicellular, marine, planktonic, cyanobacterium. Nature 277:293-294

Weisse T (1993) Dynamics of autotrophic picoplankton in marine and freshwater ecosystems. Adv Microb Ecol 13: $327-370$

Submitted: December 13, 2005; Accepted: July 20, 2006

Proofs received from author(s): November 17, 2006 